\title{
THE IMPLEMENTATION OF \\ INCARNATIONAL MISSION AMONG THE BUGIS USING CULTURAL APPROACH
}

Armin Sukri Kanna

armin_sukri@yahoo.com

sttjaffraymakassar@yahoo.co.id

\begin{abstract}
Culture as a medium to develop the cultural and ethnic identity of the Bugis was mostly denied at the early encounter of Christianity with the indigenous people in South Sulawesi. The people who were baptized had been given a new identity to identify their Christianity. But on the other hand, it brought them out from their own cultural identity that had shaped them. In several areas, Western elements influenced them very strongly, like the dress code, name, and some customary practices in society.

The history of Christian mission covers a long period and cannot be separated from the situation that prevailed in it, which can be analyzed through observing the practices, habits, and concerns of a representative sample of Christians. The diversity and coherence that appeared in every century from the first to the twenty-first of the history of Christianity should not be an obstacle in interaction between Christianity and the context. But it will be a media for observing and evaluating the totality of Christian mission in communicating the Gospel. During this process one can see how the gospel [Christ] is translated into the local forms and has been absorbed by the believers as well as transforming and discipline the believers themselves.

The Bugis Christians, in relation with these cultural-religious forms, will be able to bear witness to Christ and present him in the midst of religions and cultures. Thus, Christ can be revealed in every religion and culture as the only Savior - using the form and the meaning - but he is not the monopoly of Christians. This emphasizes the uniqueness and universality of Jesus Christ that God sent his only son to redeem and save human beings who believe in him from all religions and cultures (cf. John 3:16).
\end{abstract}

Keywords : incarnational, mission, the bugis, cultural approach 


\section{INTRODUCTION}

In contextual or cross-cultural mission, the issue of relation between Christianity and culture is a recurrent problem. This issue has created debates among many parties, historians, theologians, politicians, Christians (Catholics and Protestants), as well as non-Christians. ${ }^{1}$ There have been many arguments, which have been brought up in these debates, which are based on many different views. But in every debate and the quest for truth in it, we need to realize that every tribe or community is formed and bonded strongly with their respective cultures. Culture is deifying the land and water that provide energy for their lives; culture is their identity.

Because of the importance of culture and every element in it, then understanding one's culture is a starting point in building relationships and an effective bridge to communicating the Gospel. Based on this fact, this paper is intended for those who want to know more closely about the Bugis in order to carry out the missionary task.

\section{Geography and Demography of South Sulawesi}

Sulawesi - once known as the Celebes - is one of the major Islands of the Indonesian archipelago. This region is home to a variety of peoples and religions as well as followers of indigenous beliefs whose names are unknown. ${ }^{2}$ The island is divided into four regions - each region constituting a province - that is the northern, central, southeast, and southern regions.

The southern, central and southwestern parts of the island are bounded by the Flores Sea in the south, the Macassar Straits in the West, the Bone Gulf in the east, and the provinces of Central Sulawesi in the north and Southeast Sulawesi in the northeast. The whole area covers 28,101 square miles (72,781 square $\mathrm{km}$ ) and includes the islands of Selayar, Tambolongang, Kalao, Tanahjampea (Batu), Bonerate, and Kalaotoa to the south in the Flores Sea. ${ }^{3}$ The Southern part of the island or South Sulawesi was established as a province in 1967. The capital city of this province was known as Ujung Pandang but

\footnotetext{
${ }^{1}$ H.Richard Niebuhr, Christ and Culture (NY: Harper Torchbooks, 1975), 1.
}

${ }^{2}$ Toby Alice Volkmann and Ian Caldwell, Sulawesi the Celebes (Singapore: Barkeley, 1990), 15. The Island of Sulawesi is the best place for fishermen, for sailing and trading people, in particular the Bugis, Macassar and Mandar peoples of the south. There are lowland-dwelling people who farm a variety of plantations and numerous small groups of upland people practice slash and burn agriculture in the interior.

3 "Sulawesi Selatan" in Encyclopaedia Britannica Library, [CD-ROM] (Chicago: Encyclopedia Britannica, Inc, 2003). 
returned to its old name Macassar. It is the center of government and economic activities in this province as well as for the entire region of Eastern Indonesia.

There are four major ethnic groups and several minor ones that live in this region:

1. The Bugis, numbering about three million people are the most populous of the four ethnic groups of South Sulawesi. Most Bugis occupy the central area of the peninsula, including the broad, fertile plain between Pinrang and Watampone. Although counted as one of the staunchest of Muslims in Indonesia, the great majority of Bugis, like their Macassar and Mandar Muslim neighbours, continue to observe some older, pre-Islamic traditions.

2. The second largest group is the Macassar who numbering about one and half million people. The lands they occupy are generally less fertile (with the exception of very productive land near Maros). They depend - to a greater extent than do the Bugis - on the sea for their livelihood.

3. Another group of people called the Mandar numbering about four hundred thousand occupy the less hospitable northwestern part of the peninsula, as far north as Mamuju. Unlike the more prosperous Bugis and Macassar who occupy better lands, the Mandar never developed extensive and centralized kingdoms, but live in loosely united and relatively autonomous villages.

4. The fourth major group in South Sulawesi is the Toraja (To Riaja = the people in the North). They occupy the northern part of the peninsula and are distributed over a large and difficult terrain. The Toraja is divided into a number of sub-groups, including the Sa'dan, Rongkong, Seko, Mamasa and Mangki. About three hundred and thirty thousand Toraja live in the central highlands known today as Tana Toraja, while another two hundred thousand live in lowland towns and cities of South Sulawesi. Because they inhabit a mountainous area, the Toraja have insufficient wet-rice lands to feed their population. Many make a living by growing coffee, rice and sago.

\section{The People}

\section{Who are the Bugis?}

Christian Pelras, in his book, writes:

Although their name may sound familiar to readers of Conrad's novels or to travelers who remember having seen their smart schooners in Indonesian harbors, the Bugis have for centuries been among the most imperfectly known of the Insulindian peoples; and 
what little was 'known' about them was often in large part wrong. For example, because their boats were until recently seen all over the region, from Singapore to New Guinea and the southern Philippines to north-western Australia, it was widely thought that they had long been mainly and seafaring people, perhaps the most important one in the whole southeast Asian archipelago - indeed, some even credited them with having crossed the Indian Ocean to Madagascar - whereas in fact they are primarily farmers, and their maritime activities did not gain momentum until the eighteenth century. Their former reputation as pirates is almost entirely without foundation; and their famous Pinisi schooners, far from being hundreds of years old, took their final shape between the end of the nineteenth century and the 1930's. Their neighbors for their fierce character and sense of honor, which sometimes result in violence; know the Bugis and yet they are among the most hospitable and amicable peoples and the most faithful in their friendship. ${ }^{4}$

The ethnic Bugis, numbering more than three million, is one of the thirty-seven racial groups that make up the very varied population of the Republic of Indonesia. Their ethnic territory is in the central areas of the Province of South Sulawesi. They have over the past several centuries migrated to many other areas of Southeast Asia. There are now large settlements in the Indonesian provinces of South East Sulawesi, East and West Nusantara, East, Central and West Java, South Sumatra, Riau, Jambi and North Sulawesi. There are also settlements in the Malaysian States of Negeri Sembilan, Johore, Sabah and Sarawak as well as in the Republic of Singapore. ${ }^{5}$

The early history of the Bugis is still very unclear because of the lack of permanent stone or rock monuments that would help to provide historical data of the early history of these people to other parts of the world. Furthermore, there has not been a great deal of anthropological or archaeological research carried out in this area that could help to shed some light into the early history of these people.

The Bugis race belongs to the great family of Austronesian peoples and they have been in this area since before the Christian era. What is known comes mainly from oral history recorded from the fourteenth Century AD onward from two major sources "The $\mathrm{La}$ Galigo" texts and the Bugis Lontara. ${ }^{6}$ There are also early records

\footnotetext{
${ }^{4}$ Christian Pelras, The Bugis (Cambridge: Blackwell Publishers Inc. 1996), 3-4.

${ }^{5}$ Leonard Y. Andaya, Bugis Diaspora, Identity, and Islam in the Malay World (Macassar: International Workshop), Macassar Golden Hotel, 5-8 June 2003.

${ }^{6}$ This is a vast epic cycle written in Bugis, known as I La Galigo. Its size is estimated at approximately six thousand folio pages. Setting a meter of five and 
written by Chinese travelers in the later centuries of the first millennium and also the later reports written by Pires, a Portuguese trader who was one of the first westerners to discover this part of the world. He wrote about the Bugis:

They are men more like the Siamese than other races. Their language is on its own, different from the others. They are all heathens, robust, great warriors. They have many foodstuffs. These men in this island are greater thieves than any in the world, and they are powerful and have many paraos. They sail about plundering, from their country up to Pegu, to the Moluccas and Banda, and among the entire island around Java, and they take women to sea. They have fairs where they dispose of the merchandise they steal and sell the slaves they capture. They run all round the island of Sumatra. They are mainly corsairs. The Javanese call them Bugis (Bujuus), and the Malays call them this and Celates. ${ }^{7}$

The Bugis are originally believed to be a mainly agricultural community who settled on the fertile coastal plains of the Macassar Strait and the Gulf of Bone and the lowlands that stretch across the peninsular - north of the Southeast Cordilleras that surround the inland lakes of Tempe and Sidenreng. This area would have provided adequate land between the forests for the cultivation of rice, millet, other grains, vegetables and root crops to support the early populations. The lakes, rivers and on shore coastal areas provided an adequate supply of fish. The Bugis also became adept at plantation cultivation in their home territory as the population of surrounding areas developed and thus provided markets for their product. ${ }^{8}$ In the recent past in South Sulawesi the Bugis have been very active in developing clove, coconut, cocoa and coffee plantations. Indonesia is

occasionally four syllables, it relates even from pre-Islamic, fourteenth century Luwu, the cradle of Bugis culture. Consisting of dozens of different episodes, each with its own protagonists, and covering several generations, using a wide range of literary conventions such as flash back and foreshadowing, the epic tells the story of the arrival on earth of the gods and the adventures of their descendants. Roger Tol, A wealth of Idiom and Ideology in Toby Alice Volkmann \& Ian Caldwell, Sulawesi, 48-49.

${ }^{7}$ Fr. Manuel Teixeira, The Portuguese Missions in Malacca and Singapore (1511-1958) Vol.II-Malacca (Lisboa: Agencia Geral Do Ultramar, 1961), 10.

${ }^{8}$ Tobacco was one such product, which also included sugar cane, silkworm breeding and tree fruits. Douglas F. Toms, Foundation Pour L'aid Protestantisme Reformer (Foundation Aiding Bugis Poor Parishes: Ujungpandang, March, 1999), 34. 
now the third largest producer of cocoa in the world and the largest amount of this product is cultivated in Bugis territory.

As the population would have expanded under these favorable conditions, so the beginning of the clearance of the forest areas would have been used to supply materials for housing and boat building. The fact that they are surrounded by so much sea would have encouraged them to explore and this is the genesis of the fame that the Bugis have earned through out Southeast Asia as boat builders, sailors, and navigators. They gained proficiency in trading and developing a strong tradition of business acumen that exists to the present day which points to another reason for their migrations throughout the area. This fame has also led to perhaps the false impression that they were also hardened pirates. In the early years of the eighteenth Century, a Bugis prince led about three thousand of his adherents across the Macassar Strait, settled on the costal plain around the Mahakam River, and proceeded to cultivate the area. By contracting a marriage alliance between his son and the daughter of the Sultan of Kutei, who was up-river from Samarinda, he obtained the monopoly to trade in all of the exports from the hinterland and this led to the control of the imports needed in the hinterland. Eventually the Bugis also were granted the rights to control over trading and transport of goods between the coast and the hinterland that had previously been restricted to the Sultan of Kutei's subjects. ${ }^{9}$ This navigation and trading skill inspired Amanna Gappa to formulate an order for navigation and sea trading called 'Ade allopiloping Ri Bicaranna Pabbalue' that was accepted generally among the Bugis (from Wajo) in the entire of archipelago. ${ }^{10}$

The most significant element that is found in the Bugis community is culture. Many specific forms of cultural elements inherited from the past are still being practiced today and have been considered as an important aspect of the cultural identity of the Bugis. This identity holds firm to preserve and protect their ethnicity that enables them to survive over the centuries, although the circumstances around them are always changing.

${ }^{9}$ One of the earliest illustrations of this migration and entrepreneurial spirit is shown by the settlement of Bugis in the area of Samarinda, in East Kalimantan. Toms, Foundation, 33.

10 Andi Moen, Menggali Nilai-nilai Budaya Bugis-Makassar dan Sirik Na Pacce (Makassar: Yayasan Mapress, 1988), 159. 


\section{The Role of Culture in Shaping of the Bugis Ethnic Identity}

The classical age of the Bugis community was known as La Galigo culture. It was the original source of the Bugis culture in pre-Islamic era. In the La Galigo texts, it was discovered that the Bugis culture was centered more upon the divine than the mundane. The rituals, festivals, entertainments, house form, and warfare - as the elements of the Bugis culture - were seen in connection with supernatural power.

Bugis culture is compiled into a system called Pangaderreng (customic system) which consists of five components: Ada' or tradition, Rapang or norm/ethic, Wari or social structure regulation, Bicara or rights and obligation, and Sara (syariah) or law. Every single person in the Bugis society is bound integrally to this system which was given a normative guideline to manage their lives in peace and prosperity. This system develops form of leadership, social interaction, rule and regulation, ritual and ceremony, and religious belief.

One of the most basic element in the Bugis life is siri', which literally means 'shame'. But in the Bugis cultural context this term may mean honour, dignity, and courtesy. Siri' is applied as personal honour and communal honour in the daily life of the Bugis. "In the ancient Bugis tradition, every person or community must protect himself or herself from doing anything that will go against this concept. Whoever does not respect others or community will face a grave penalty that can sometimes result in the death penalty.

In terms of relationship, the Bugis stand on principles: rebba sipatokkong, mali siparappe, sirui menre' tessirui no', malilu sipakainge'-mainge'pi mupaja (support each other, encourage each other, love each other, and reminds each other). Other principles related to this: ${ }^{12}$

TauE ri Dewata (Fear of God).

Siri'E ri watakkaleta (Respect for Oneself)

Siri'E ripadatta rupa tau (Respect for Others)

These principles are the legacy of the Bugis ancestors given to the future generations. The next generation, can learn from the high values of their cultural context. Through these cultural norms, the younger generation can use these significant values and transform them into reality in their lives. In fact, the Bugis society develops its character through culture and uses it as a guide in life. When Kajao

\footnotetext{
${ }^{11}$ Nurman Said, "Religion and Cultural Identity among the Bugis" in Inter-Religio Bulletin, no.45, summer 2004.

${ }^{12}$ Moen, Menggali, 25.
} 
Lalliddo ${ }^{13}$ became a teacher to the Bugis royal family in Bone kingdom, he emphasized five themes as the foundation of moral education: ${ }^{14}$

- Lempu (Honesty)

- Siri' (Honor)

- Ada tongeng nasibawangngi tike' (Truthful in word and deed)

- Awaraningeng nasibawangngi pammase (Bravery with love)

- Mappesona Ri Dewata seuwae (Submission to God)

Tradition seems to be the main element that unites every level of community. Even in the Bugis communal system, tradition seems to be the main connection that keeps the community united. Tradition places the elements of society in harmonious order without denying the rights and obligations of each individual. To put it shortly, tradition is the catalyst for good values, which help create a transformation that is not self-centered but collective as a community. Realizing how tradition is important, it is not strange that the Bugis hold onto the principle of Siri' emmi ri onroang ri lino, utettong ri ade'e. Najagainnami siri'ta naia siri'e sunge' naranreng, nyawa nakira-kira (Because of this dignity we live in this world, to honour our tradition. Because we guard this dignity we willingly offer our lives as a sacrifice). ${ }^{15}$ Standing firmly on their culture enables the Bugis to survive over the centuries although the circumstances around them are always changing.

\section{Structure of the Society}

\subsection{Kinship}

Kinship is reckoned bilaterally - that is, through both the father and the mother. Among the nobility, many of the marriages are still arranged by parents or grandparents, and usually take place between close cousins. This is done to preserve the purity of the bloodline and to keep the wealth within the family. Newlywed couples often live with the wife's family for the first few years of their marriage. Divorce is a common occurrence among the Bugis, particularly between couples united in arranged marriages.

\footnotetext{
${ }^{13}$ Kajao La Liddo is the one of Bugis wise men in the past that succeeded in practicing his teaching in society. With reference to the writings of the Bugis-Macassar, the role of Kajao La Liddo was said to be that of a great thinker and a great diplomat of his country.

${ }^{14}$ Moen, Menggali, 17.

${ }^{15}$ Moen, Menggali, p. x. See Andi Zainal Abidin, Capita Selecta Kebudayaan Sulawesi Selatan (Ujungpandang: Unversity Press, 1999).
} 
Daughters usually inherit the house, while land and other wealth are divided equally among both sons and daughters.

Kinship plays a very important role in the Bugis society and it is given more priority than any other relationship. Every member of the household is involved in decision-making toward any matters occurring within the family. It happens quite often that an important project or plan could not be realized because of disagreements among family members. Kinship also influences the decision of a member of the family who wants to change his religion especially to Christianity. Many Bugis have revoked their intention to accept Christianity because of objections from their family. However, it has happened that sometimes the entire family has followed the repentance of one family member.

\subsection{Social Stratum}

Within Bugis social stratum there is a general system, which can be found in every group in society, either in a small or large scale. As we analyze these structures and other social stratum in the various Bugis kingdoms, we can conclude that in Bugis society there are three different levels or classes. The first level consists of the Nobles (King and relatives and other aristocrats), then followed by the second level, that is, Commoners (People with different professional backgrounds who are considered as free people), and the third were slaves (People who are under the control of others and who do not have any freedom rights). This structure is shown below:

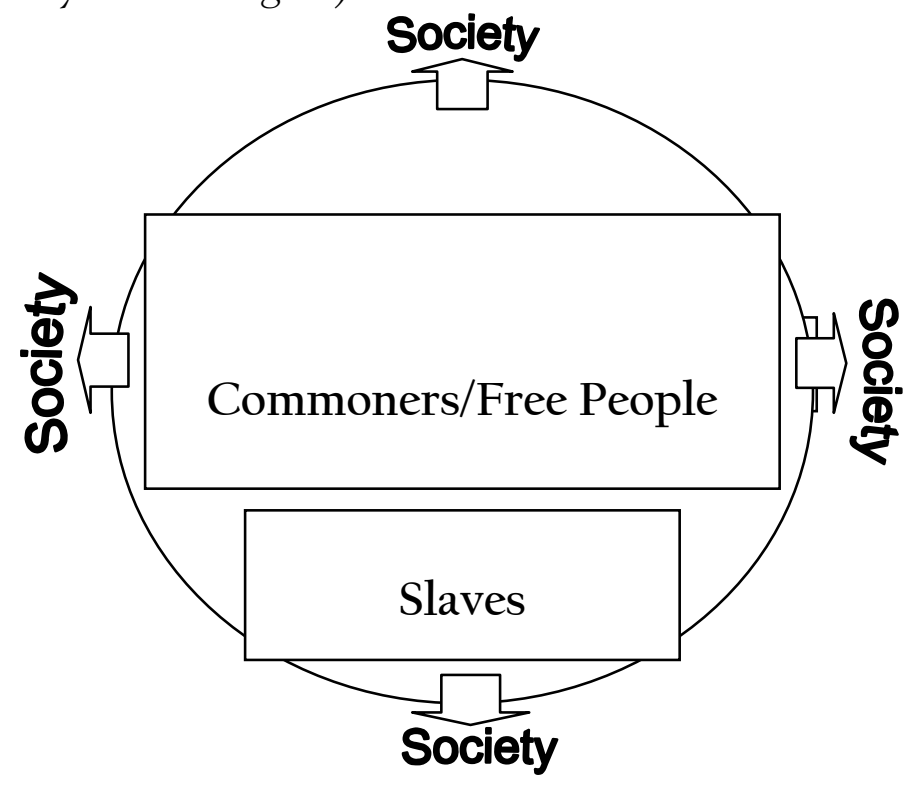


In fact, this social stratum does not differ much with any other social stratum among other societies in the world. Yet according to Hamid Abdullah, the uniqueness of the Bugis social stratum can be seen in the penalty which is given to the person who breaks it, for example, interclass marriages. The person is severely punished and can be sentenced to death or lose his social rank. ${ }^{16}$ This offense is categorized as customic crime, because the social stratum is a part of the customic system in the Bugis society.

Since the end of the kingdoms, the Bugis society is roughly divided into two levels, the nobility and the commoners. The nobility are those who are descendants of the former ruling families with limited intermarriage with commoners. Their status is based on the rank of both parents. Today it is easier for the commoners to gain status through professional prestige, education and wealth. Among the Muslims this status can also be gained through the carrying out of the Hajj.

\subsection{Leadership: The Pattern of To Manurung}

The level of To Manurung ${ }^{17}$ leadership in the Bugis-Macassar society is the beginning of social stratification, political and authoritative systems. Previously, authority in Bugis-Macassar society did not have a proper form even if each district had its own leader. As an example, in the Macassar region in the present time, nine small kingdoms joined as a federation under the leadership of Paccallaya. But Paccallaya does not act like a king. Instead, he is only a symbol who has no direct influence to the regions that are integrated with in the federation. Each region, as member of the federation, has autonomy, which gives it the discretion of free action. Because of these rights, these regions always compete with each other which has thus brought them conflict and chaos. ${ }^{18}$

The presence of To Manurung in this situation has created a new hope among the people for a new order that will give them peace and prosperity. This character is believed to have come from the world above [heaven] with particular characteristics which

\footnotetext{
${ }^{16}$ Hamid Abdullah, Manusia Bugis Makassar (Jakarta: Inti Idayu Press, 1985), 115.

17 The presence of To Manurung in the history of Bugis-Macassar or in the formation of their society remains a mystery. The oral tradition story of Bugis and Macassar recounted that To Manurung is a woman but there is no strong evidence to clarify the reason why she appeared or what is the purpose of her appearance. It is difficult to explain this level because there is no accurate evidence that can be referred to, as explain the pedigree of this figure.

${ }^{18}$ Abdullah, Manusia, 74.
} 
distinguish her from ordinary people in this world. She is a mighty creature who is equipped with sacred elements to strengthen her authority in society. The leadership of To Manurung and her presence in this world does not only have a symbolic meaning, but it directly interacts with human reality. Furthermore, according to tradition, she married ordinary people and then her descendants continually lead the Bugis and Macassar people. ${ }^{19}$

The leadership pattern in Tomanurung tradition has created a unique understanding among the Bugis people in particular. According to their understanding the leader or king is a person who has more abilities than the people he leads. These abilities include spiritual and physical, like bravery, cleverness, wealth and religious faith. Later on, Islam became a basic religious appraisal for leadership. The significance of these aspects is that leaders must be good models or examples in fidelity to the traditions without bias. ${ }^{20}$

The understanding of 'charismatic' leadership and total subjugation to the leader had a great influence in the mission world. This understanding is useful as a model of mission to communicate the gospel to the society. This model uses 'top-down' method, which is the gospel, firstly communicated to the king or leader and then his followers will naturally follow. This method is known by the motto 'my king's religion is also my religion' (which is comparable to the principles, which was followed during the dissemination of Christianity in Europe, 'Cuius regio, euius religio'.

\section{Cultural Religiosity}

\subsection{Mythical Dimension}

The Bugis may have been among the earliest converts to Buddhism or Hinduism in Southeast Asia. However in the early

${ }^{19}$ To Manurung came down from heaven to the earth in a place called Taka'bassia. Paccallaya and the other leaders requested her to be their highest leader. After accepting their request, she became their highest leader, and then To Manurung was married with ordinary people. See Abdullah, Manusia, 70-75.

${ }^{20}$ This significance is reflected in the following proverb, 'tradition [adat] does not know your child and grandchild' [the proverb of La Pagala Nene Mallomo in the sixteenth century]. It means that to follow the traditions, the leader [or people] should not compromise even with his own family or person who is really close to him. This understanding then motivated the people to submit their life and totally subjugate themselves to the leader as the centre of the new order. This subjugation is reflected in the following proverb: Angikki', naurauk kayu. Kegaki' mangiri, kuwatokka tappali [Your majesty is the wind and we are the dry leaves. Wherever you blow, we will fly there]. MPS-GKSS, Angin Menderu, Ombak Mengguncang: Sejarah Singkat Gereja Kristen di Sulawesi Selatan (Makassar: MPS, 1996), 21. (Translated by the author) 
1600's, they were forced to convert to Islam by the Sultan of Macassar. The Bugis ancient tribal religion was animism and their ritual was known as Tuanni. This involved the worship of several gods such as the "land god", the "rice god", and the "god of kings." They also believed that the "spirits" of fire, air, earth, and water inflict certain illnesses and misfortunes on people. This religious pattern is found in the earliest Bugis society. However, in certain places, it is still practiced together with Islam and other religions.

Generally, the original religions that are practiced by native tribes who remain in the southern part of Sulawesi are similar in form and emphasis. Among these religions there is a concept that emphasizes the presence of the Dewata SeuwaE (the Supreme Being), who is believed to be the ruler of heaven and earth as well as the original source of all things. The relationship between human beings and the Dewata SeuwaE is manifested through worship and sacrifice, which symbolizes respect and appreciation for the protection and prosperity given to them. On the other hand, the Dewata SeuwaE demands humans to pursue lives that are orderly, honest, sincere, and balanced with nature. Those religions also emphasize the messianic and Incarnational aspects, which believe that god reveals himself in human form to bring peace and prosperity into society. ${ }^{21}$

The Bugis religious worldview, recorded in Lontara La Galigo ${ }^{22}$, shows that the Bugis original religions contain mythological aspects. This narrative covers the story of the origin of human beings or creation, the beginning of Bugis land, the relationship between humans and gods, and other 'supernatural' stories. Although the distinction between the spirit world and the natural world [reality] is strongly emphasized, these two worlds could be connected through the incarnation. The Lolobadjo religion has found in this concept that one of the important characters in this religion, known

${ }^{21}$ Among the Bugis, the Dewata SeuwaE is believed to be incarnated in Petta Barang [the Lord from Barang]. In the region of Sidenreng Rappang, the belief of Toani Tolotang which means the inhabitants there worships many lesser gods and Dewata SeuwaE, their greater god. The Amma Toa belief recognizes Tau Ri'e A'ra'Na as its Dewata SeuaE. In other places, the Dewata SeuwaE is recognized as Karaeng Siwa, Karaeng Kaminang Kammaya, Karaeng Ampatana and Karaeng Tunappilelae. In the oldest form of worship known as Lolobadjo in the Bugis territories, a prominent person by the name of Saweregading represents the significant gods in La Galigo, an original Bugis poem. This god is found almost in all the tribal beliefs - which change according to time and place - but is revered interchangeably according to the context. See Chris G.F.de Jonge, Ilalang Arenna (Jakarta: Gunung Mulia, 1996), 15.

${ }^{22}$ Roger Tol, A wealth of Idiom and Ideology in Volkman \& Caldwell, Sulawesi, 48-49. See also Pelras, The Bugis, 32-34. 
as Saweregading was believed to be a god who had incarnated into human form and founded the leadership in Luwu.

According to the Bugis chronicles, it was near the Cerekang River, between the present towns of Wotu and Malili, that the gods first descended, and that their descendent, Saweregading performed his legendary deeds. The first Bugis kingdom may have been located here, perhaps in the thirteenth and fourteenth centuries, and may provide the historical basis for the tale. ${ }^{23}$

The paragraph below is a story of creation taken from Lontara La Galigo:

In the beginning, the light was shining, and then To Palanroe (the creator) rose from his sleep and looked down. Rumamakompo knelt down before him, and said, "May the Lord send a son [human] into the earth, to worship and glorify you. To Palanroe spoke, "Depart oh my son, La Togelangi, down into the earth. I will make you a shoot in the earth! You are my son and I will hear your requests and fulfill your will. Then, Saweregading was born with his armour, and everything calmed down.... ${ }^{24}$

Hamid Abdullah in his analysis of the Lontara La Galigo, argues that based on the historical view, the La Galigo literature cannot be a primary source to develop a concept of human behaviour in the natural world. According to him, this literature is a result of imagination and developed amongst the palaces of the nobility of its time. The stories in this literature do not relate to human reality. ${ }^{25}$ However, based on cultural-religious factors, this literature has provided a great contribution in answering some questions regarding the origin of the natural world. The mythological tendencies, which are found in all primal religions, look irrational, but through it, people can see the continuity between the supernatural world and the natural world.

The myth of creation in the original Bugis religions can be compared with the story of creation among other religions and cultures around the world. This comparison can be explained based on missiological perspectives that the stories that are identified as myths can possibly contain elements of truth. Because, if this comparison refers to the absolute truth - in Christianity this is

\footnotetext{
${ }^{23}$ Volkmann \& Caldwell, Sulawesi, 106. (Translated by the author)

${ }^{24}$ Abdullah, Manusia, 119. (Translated by the author)

${ }^{25}$ Abdullah, Manusia, 120.
} 
known as the God who has revealed himself in Jesus Christ [logos] then we can see the similarity of this concept, that is the world and all that is in it was created by the Supreme Being (Cf. Genesis 1:1-31; 2:1-25). The Supreme Being who created all things has revealed himself in various contexts, forms and terms as well as religions and cultures.

\subsection{Petta Barang. The Messianic Expectation}

Petta Barang [the Lord from Barang or Pabarang] is a legendary Bugis figure who was probably born in the mid nineteenth century in Kampong [village] Tile, located in Lamuru and Tanete, under the authority of the Bone Kingdom. His real name is Lampe'e which means "the tallest." The stories of Petta Barang then compare with the stories of Arung Palakka, the King of Bone, XVI who was enthroned in the 17 Century. However, this concept is not reasonable because there is a long period between them. ${ }^{26}$

The figure of Petta Barang is a symbol of confrontation against the Dutch presence in South Sulawesi and the Bugis region in particular. After the Dutch conquered Bone, Wajo, Soppeng, Sidenreng-Sawitto, and Luwu in three campaigns from 1859 - 1905, he moved into the jungle with his followers and continued to fight against the Dutch invaders but was captured in 1913 and exiled to the island of Java where he eventually died. ${ }^{27}$

During the confrontation against the Dutch invaders, the people created many stories regarding the supernatural power of Petta Barang. This following story is one of the stories told by Zainuddin to de Jong:

Petta Barang told Pattawe that he could perform miracles. When he was surrounded by Dutch troops in Barru, he was in the mountains [bulu lagolla]. In this situation, he asked his followers to close their eyes. When they opened their eyes, they were very surprised because Petta Barang had moved to another mountain [Copok Kapiring]. The distance between these two mountains was very far but he was able to jump there. ${ }^{28}$

${ }^{26}$ Chris G.F. de Jong, Ilalang Arenna (Jakarta: BPK Gunung Mulia, 1996), 198.

${ }^{27}$ de Jong, Ilalang, 198.

${ }^{28}$ The stories about Petta Barang's supernatural power continued to develop amongst the people, especially after someone appeared and proclaimed himself as Petta Barang who escaped from death. In the people's imagination, Petta Barang became a liberator and saviour who developed a reputation that was far bigger than the one he had when he was still alive. In fact, Petta Barang cannot be categorized as one of the religious messianic characters found amongst the Bugis original religions. The 
The Bugis religious world view, which focused on mystical elements, when mixed with their expectation of liberation and redemption turned Petta Barang into a messianic figure. He promised his followers that their expectations would be fulfilled when he returned to the world for a second time. Furthermore, this movement also became an anti-Islamic symbol when it tried to forcibly convert people. Zainuddin revealed the expectation of the second coming and his attitude against Islam:

Petta Barang taught about salvation and said that he would return to this world after he died... His reply was that people would come and bring to you a scripture, which does not mention anything about Muhammad. You should believe it because it brings salvation to you. ${ }^{29}$

The promise that he would return and complete his mission to save and redeem his people, and also 'the scripture' that did not mention Muhammad became the reason why Christianity can be accepted amongst his followers.

Culture plays a significant role in the values of the Bugis society to which every person is fully tied to. Culture is not only holding firmly in term to bind every single person into communal system but also to shape the Bugis ethnic identity. By standing on the principle: Siri' emmi ri onroang ri lino, utettong ri ade'e. Najagainnami siri'ta naia siri'e sunge' naranreng, nyawa nakira-kira (Because of this dignity (siri) we live in this world to honour our tradition. Because we guard this dignity (siri), we willingly offer our lives as a sacrifice; the Bugis are able to protect their identity whether in their homeland or in Diasporas.

Doing mission among the Bugis in the contemporary context must be based on key issues occurring in its setting, so that Christian mission as an incarnational mission is able to be implemented. As we look at the world today from the historical perspective, we realize that the history of human beings has been changing from time to time, from the first century up to the twenty first century today, bringing more complexities of life. Nevertheless,

liberation movement that he led was no more than a socio-political reaction towards the Dutch invasion of the Bugis lands. Nevertheless, this movement was later transformed into a religious one when his followers equated his supernatural power with other characters in the Bugis primal religions. de Jong, Ilalang, 198-99. (Text translated by the author)

${ }^{29}$ de Jong, Ilalang, 201. (Translated by the author). 
these indications should not become obstacles in the interactions between Christianity and the world, but rather challenge the nature of Christian mission. In this challenge, Christian mission should bring transformations in 'double' dimensions, the mission and the world.

\section{Understanding of Mission}

\subsection{Missio Dei}

The statement of commitment about Church and Mission in the Iguassu Affirmation said that:

The church in mission is central to God's plan for the world. We commit ourselves to strengthen our ecclesiology in mission, and to encourage the global church to become a truly missionary community in which all Christians are involved in mission. In the face of increasing resistance and opposition from political powers, religious fundamentalism, and secularism, we commit ourselves to encourage and challenge the churches to respond with a deeper level of unity and participation in mission. ${ }^{30}$

In churches today, there is growing interest in evangelism and mission. However, only a few of them really understand that mission must be according to the pattern that God revealed in Jesus Christ. The statement of commitment of Church and Mission in the Iguassu Affirmation brings Christians to this basic understanding of mission. This understanding is central to God's plan for the world, which was through the Incarnation. Each Christian received the same commission from our Lord to:

Go therefore and make disciples of all nations, baptizing them in the name of the Father, the son, and the Holy Spirit, and teaching them to obey everything that I have commanded to you... (Matthew 28:19-20, NRSV).

How can Christians interpret this commission and carry out mission that effectively communicates the gospel in the Bugis context? The answer is not simple. Mission is not merely a desire to "reach out and grab", but also involves form and strategy and many other components of mission. Christian mission must stand on the

\footnotetext{
${ }^{30}$ William D.Taylor (ed.), Global Missiology for the $21^{\text {st }}$ Century (Grand Rapids, MI: Baker Academic, 2000), 19.
} 
Lord's promise, "Remember, I am with you always, to the end of the age" (Matthew 28:20, NRSV).

Based on this statement and in addition, the fact that Christians or churches struggle to find the answer to this question believers should come to the understanding of mission as God's mission Missio Dei. It is God's intention or God's purpose for the world. God has a plan and action for the world and God's action in the world. It is God and the world and it is a Grand Scheme. ${ }^{31}$ God told Jeremiah who was just a young man, "Now I have put my words in your mouth. See, today I appoint you over the nations and over the kingdoms, to pluck up and to pull down, to destroy and to overthrow, to build and to plant" (Jeremiah 1:9-10, NSRV).

As God called and appointed Jeremiah over the nations and over the kingdoms, He has also called Christians and Churches and sent them for a faithful ministry of witness, summoning the disobedient to turn to God. They must do this from the context of their lives, where God is truly worshiped, the faithful built up, and compassion demonstrated. This is the true Missio Dei, and foreruns the true shalom that will be realized in full at the Lord's return. The missionary activity of the church is thus brought into close relationship with the missionary activity of God himself. Thus, the church takes its place in the service of God for the proclamation of his gospel. The church cannot really be the church of God unless it takes its share in the mission of the Son. ${ }^{32}$

If this movement among the Bugis church is observed then it will be found that it is not the mission objective to motivate the members to share the gospel as an outward missionary movement. Mission work had focused much attention only on the problems that appeared in the church and faced by its members, but mission in its true meaning to witness and to bring in new believers was denied. Definitely, it is not easy for this to be formulated in the mission theory, because there are many determining factors that relate to each other in this situation. Cultural formation, social

\footnotetext{
${ }^{31}$ Vinay Samuel, "Mission as Transformation" in Evangelical Perspective on Mission and Ethics. Dristikone magazine: April-July 2002. 3.

${ }^{32}$ Georg F. Vicendom, "Missio Dei" in Stephen Neill, Gerald Anderson \& John Goodwin, Concise Dictionary of the Christian World Mission (London: Lutterworth Press, n.d), 387. Mission thus comes to be seen as the basic function of the church. It would, however, be too narrow an interpretation of the term Missio Dei, if the idea were limited solely to that God actually does, for communication of salvation. Vocation, preparation, the sending out of workers, and carrying out of their manifold forms of service, are ways in which the love of God, defined by the Missio, finds visible expression.
} 
stratum, characteristic, and religiosity of the Bugis have a strong influence on the missionary movement among them.

In addition, the influence of Islamic values slowly inculcated into the Bugis culture and later, accepted indirectly as the Bugis official religion occurred as a great challenge to the Christian mission. Especially, the history of the Bugis Christian movement which is full of tears, suffering, and oppression from the Muslims, has been a dramatic impact on the Christian paradigm of mission among the Bugis until today. This condition is the reason the Bugis church does not respond fervently to mission work, particularly when it encounters people from other religions, specially the Muslims. However, if there is increase in number among the Bugis Christians, it is because of the biological factor.

Contrary to the Bugis Church, the churches that are not considered as the local churches, e.g. Chinese Churches, Korean Churches, International Fellowship, and various mission organizations - OMF (Overseas Mission Fellowship), Frontier, WIM (World Indigenous Mission), Seamist (Southeast Asia Mission Team), WOH (World of Hope), and so on - which are working in South Sulawesi are giving serious attention towards the missionary movement among the Bugis.

\subsection{Incarnational Mission}

H. H. Rowley finds the meaning of mission in the Old Testament, and suggests that Moses was the first missionary. At the same time, he reminds us that Israel never became a missionary community in the modern sense of the term.

Enough has been said to demonstrate that the Old Testament is a missionary book. Yet it is undeniable that Judaism is not essentially and notably a missionary religion. That it knew some missionary impetus, and some proselytizing zeal, may be allowed without contradicting this. Yet there never has been the slightest likelihood of its becoming a world religion, in the sense which Christianity has been a world religion from the first century of its existence. $^{33}$

Rowley has understood the Old Testament as a book where God's mission began from creation. He understands the history of the world from the viewpoint of Missio Dei. God works and reveals himself in human history. The Bible talks of how God worked with

${ }^{33}$ Kane, Christian Missions, 17. 
the nations. When God showed himself in miraculous acts on behalf of Israel or in punishing a nation, He was acting in history. That is how the prophets saw it. God intervened through the course of human history but never violated human freedom. History is governed - neither by fate nor by chance - but under God's action in everyday life; individual and corporate. ${ }^{34}$

The Israelites defined God's mission by his actions in delivering them from Egyptian captivity. His actions became the foundation for his continued interaction with Israel. God's covenant, for instance, was based on what God had done in Egypt when he carried Israel "on eagles' wings" and brought them to himself (Ex.19:4). God's mission of deliverance was based on his eternal attribute of love (Ex.34:6-7). ${ }^{35}$ God then sought a person to carry out his mission. At the burning bush, Moses was given the commission to be God's missionary of deliverance (Ex.3:10). This call itself shows that the mission was God's; it was not a deliverance improvised by human ingenuity. ${ }^{36}$

There is also the larger picture of Mission. We have in the Old Testament God with all the nations, taking one nation, using it as a symbol, as a sign of the way in which He expresses his character, divinity, sovereignty, love and power in creation. God's missionary role in the Old Testament is focused on his will and his direction. He is working through people who were chosen to accomplish his purpose in the world.

In days to come, the mountain of the Lord's house shall be established as the highest of the mountains, and shall be raised above the hills; all the nations shall stream to it. Many people shall come and say, 'Come, let us go up to the mountain of the Lord, to the house of the God of Jacob; that we may walk in his paths.' For out of Zion shall go forth instruction and the word of the Lord from Jerusalem. ${ }^{37}$

Mission is also the central theme of the New Testament. From the beginning, God revealed his mission to humanity in many diverse ways. Yet the mission of God became real in human life through the incarnation. The consistent theme throughout the New

\footnotetext{
34 Samuel, "Mission," 3.

35 Gailyn van Rheenen, Biblical Foundations And Contemporary Strategies Missions (Grand Rapids, MI: Zondervan Publishing House, 1996), 15.

${ }^{36}$ van Rheenen, Biblical Foundations, 15-16.

37 Isaiah 2:2-3, NRSV.
} 
Testament is based on God's great love, fulfilling his mission through Jesus Christ:

For God so loved the world that he gave his only son, so that everyone who believes in him may not perish but may have eternal life (John 3:16, NRSV).

This verse shows God, through Jesus, initiating His mission of reconciliation. The mission of God through Jesus Christ is the mission of salvation. This mission is not based on human works. God initiated this mission while we were still in rebellion against him, alienated from his presence, and living in sin.

The central message of Christ's ministry proclaims the message of the Kingdom of God. A fuller summary of Christ's message is given in Mark's Gospel: "The time has come...The kingdom of God is near. Repent and believe the good news" (1:15). In this passage, "the time has come" is synonymous with "the kingdom of God is at hand. ${ }^{38}$ The biblical concept of kingdom, however, predates the coming of Christ. The word means the "rule, reign, or sovereignty of God." The synonymous parallelisms of Psalm 145:11-13 define the nature of the Kingdom of God:

They shall speak the glory of your kingdom, and tell of your power, to make known to all people your mighty deeds, and the glorious splendor of your kingdom. Your kingdom is an everlasting kingdom and your dominion endures throughout all generations (Psalm 145:11-13, NRSV).

Christ proclaimed the kingdom in both word and deed. He preached "the Good News of the Kingdom" (Luke 4:43). The first three petitions of the Lord's Prayer summarize the essence of Christ's kingdom proclamation: Hallowed be your name; your kingdom come; your will be done on earth as it is in heaven (Matthew 6:9-10). The people

${ }^{38}$ Gaylin van Rheenen, Biblical Foundations, 20-21. The term "near" has both present and future connotations. It means "'drawing near,' 'breaking in,' 'in process of becoming' "(Ferguson 1989, 24). In this passage, "the time has come" is synonymous with "the kingdom of God is at hand." The first phrase "looks backward. While the second look to the present and future; the first announces the end of the old era, the second proclaims the beginning of the new" (Ambrozic 1972, 21-22). Beasley-Murray interprets this passage to mean, "If the time before the kingdom is finished, the time of the kingdom has begun" $(1986,73)$. The coming of Jesus Christ, therefore, formed the watershed of the ages, a turning point in history, a time for the breaking in of the mighty reign of God in his Messiah. 
of God have always proclaimed the Kingdom of God. This message is a sense of God's purpose in humanity, which is related to the sacrifice of Jesus to save the world. This message must be proclaimed to all people, so they will know the sense of the truth and receive redemption in Christ.

\section{Basic Forms of Christian Missions among the Bugis in Cultural Approach}

\subsection{Contextualization}

The major issue customarily faced by missionaries who come from a different setting is to find mission forms which are appropriate and applicable in the local context. Dealing with this issue every single missionary should realize that the form must be based on context with its elements rich in communication source to engage with the people. It will also help missionaries to avoid the danger of transferring their own setting (culture) into the local context to prevent cultural clashes.

The same rule has to apply in Christian mission among the Bugis when missionaries commit to share the gospel in the midst of the suspicious and even hostile Bugis community. Their commitment has to be followed by appropriate and applicable forms that are based on the Bugis setting and world view. To consider the issue of contextualization, Pharsall says:

"Contextualization" is a word, which has recently come into popular usage among evangelicals. The word itself directs our attention to the "context". This includes the total matrix of society, which embraces the social patterns of a people, their economic policies, politic, and a host of other integrative areas. In this part, the gospel of Jesus Christ must be attractively presented into the context of any given group of people. This is a process, which involves great sensitivity.

Contextualization will enable missionaries to identify the local setting and adjust their own life pattern to be intertwined in it. Nevertheless, contextualization in term of Christian mission is far from the act of just to compromising with the local setting without any critical assessment. On the other hand, every single missionary has to determine that the gospel which is proclaimed in a particular context brings about transformation to the local setting involving whole areas of life. The Ministry of Paul in early Christianity is a prime example of appropriate form and successful contextualization

39 Phil Parshall, New Paths in Muslim Evangelism: Evangelical Approaches to Contextualization (Baker Book House: Grand Rapids, 1980), 31. 
of the gospel (1 Corinthians 9:19-23). Therefore, the two significant forms below are considered as challenges to the Christian mission among the Bugis with intention to provide appropriate forms of contextualization in the contemporary context.

\section{a. Cultural Orientation}

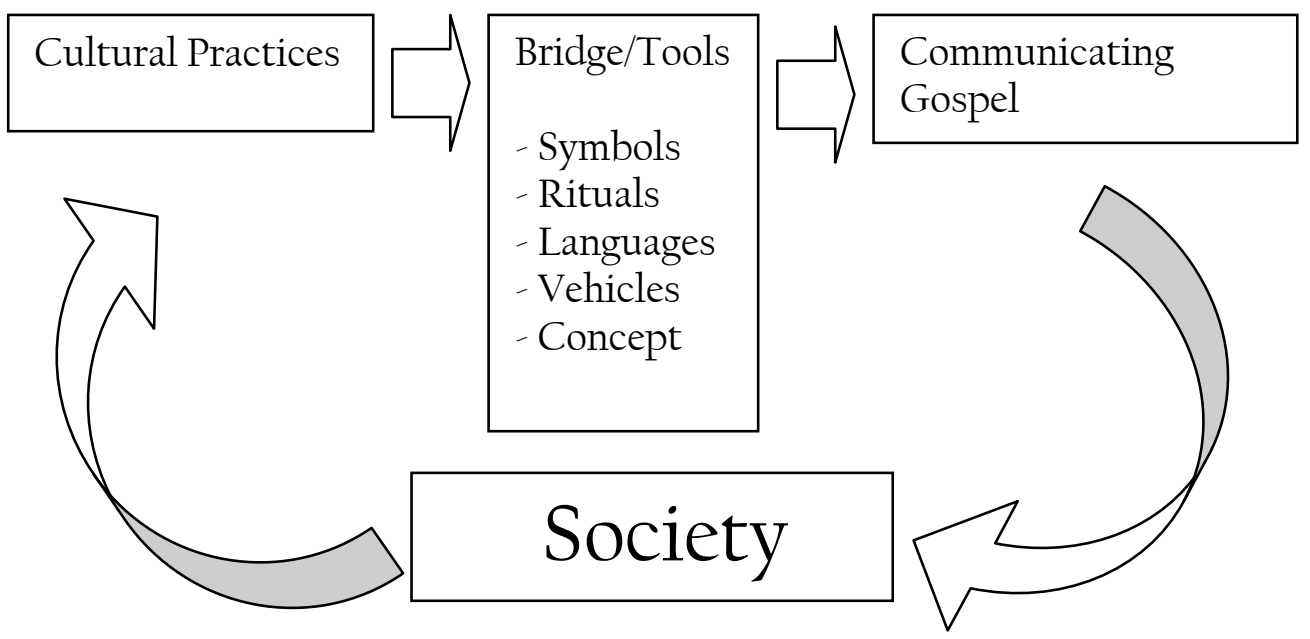

The diagram displays the way to proclaim the gospel in a particular context or culture using the cultural elements, like symbols, rituals, vehicles, concepts, and languages as a bridge of communication or medium of engagement. The religious-cultural ritual shown below is an example of the implementation of this form in the Bugis context:

The Bugis shaped their religious system based on belief in the Spirits that center around the Supreme Being before Islam and Christianity dominated them. As this religion was tightly integrated with the Bugis culture, the rituals and practices were accepted generally and shaped their worldview in understanding all things linking to the powers surround them. In this religion, they worshiped gods and goddesses related to their works and phenomenon of the nature. One of these goddesses worshipped by the Bugis people especially among the farmers was Sang Hyang Seri (Rice/Paddy goddess).

At the end of the harvest season, the community celebrates the thanksgiving festival to Sang Hyang Seri. They bring rice, fruits or cattle to offer before the goddess through some rituals that symbolize their thankfulness upon her grace of fertility. After the ritual procession, it continues with the communal feast in which 
every body share their joy. This religious festival is being practiced among the Bugis community recently although in different form. But the meaning still remains as an event of thanksgiving for the grace that they have received.

In missiological encounter, it is an effective media or bridge to communicate the gospel among these people. This event and its basic meaning of thanksgiving can be used to penetrate biblical values inside. The bible teaches to give thanks in all circumstances as well as for every blessing and that it comes from God who is the provider. We give thanks not to a god or goddess but to God who provides the harvest for us. In addition, it is significant to teach them about the mighty power of God, the creator of the world and its vast array. He is the Lord of the land and the plants. He has blessed farmers with harvest and we give thanks for it.

\section{b. Transforming Cultural Values}

This form intends to acknowledge some cultural values or principles that contain essential truths similar to the Biblical values in its substance and use them as medium for transformation in the Bugis community. During the time of Kajao Lalliddo who carried out his task as a private counselor to the king of Bone and official teacher of the royal family, he emphasized five principles as the foundation of moral education in daily life.

- Honesty (LempuE)

- Honor/Dignity (Siri')

- Truthful words and good deeds (Ada tongeng nasibawangngi tike')

- Bravery with love (Awaraningeng nasibawangngi pammase)

- Total Submission to God (Mappesona Ri Dewata Seuwae)

There aresimilarities of emphasis regarding morality that can be found in the bible, such as: honesty (Ec.7:29; 12:10; Prov. 2:21; 16:7), good deeds (Prov.11:17), bravery and love (Prov.2:16; Job 6:14; 10:2), and total submission to God (Prov.2:5-7). The Biblical teachings of morality in daily life can be translated into these principles and used them to transform the Bugis community. This transformation will bring to understanding that God is the source of wisdom and he gives it to everyone who asks for it. Christians should let infinite wisdom come through the illumination and inspiration of the Holy Spirit and pray expectantly for wisdom that will enable every single person in the community to apply these principles in their daily lives.

With the intention to apply these forms into the local setting, every missionary needs to be warned of the danger of syncretism 
which often happens in this way. In addition, beliefs and practices will flow from the missionary and his own cultural background to the receptor and therefore, will also contribute to appearance of this problem when these beliefs and practices mix with the indigenous setting. Paul G. Hiebert has marked this issue:

Not only must we separate the Gospel from our own culture, we must seek to express it in terms of the culture to which we go to. The people may sit on the floor, sing songs to native rhythms and melodies, and look at pictures of Christ who is Black or Chinese. The church may reject democracy in favor of wise elders, or turn to drama to communicate its message. However, as we have seen, translation involves more than putting ideas into native forms, for these forms may not carry meanings suitable for expressing the Christian message. If we then, translate it into native forms without thought to preserving the meaning, we will end up with syncretism-the mixture of old meanings with the new so that the essential nature of each is lost. ${ }^{40}$

Every religion stands in danger of the effects of syncretism, especially in the process of cultural engagement. Christianity in the midst of the Bugis is not fully free from these effects. The Bugis Christians, in a particular area, often practice their cultural rituals without critically examining them or basing them on Biblical values. In the rural areas of the Bugis heartland we can easily find Christians who still practice occultism and idolatry, in which they believe there are other powers [spirit] beside God. They believe that these spirits remain and control particular places or objects that are linked to their daily lives, such as houses, lands, water sources, etc.

Christian mission plays its role in Missio Dei to proclaim the gospel and make it incarnate in the context. This role puts Christian mission in a significant position, as God's agent for transformation ${ }^{41}$ and guardian of culture without syncretism. Learning from the New Testament, Paul showed the pattern of cultural engagements in Acts 17:16-34. Paul used the local religious form and changed its meaning with the gospel message. Christian mission could use the Bugis forms based on the gospel and put new meaning in them.

\footnotetext{
${ }^{40}$ Phil Parshall, New Paths, 25.

${ }^{41}$ Similar idea in Sherwood Lingenfelter, Transforming Culture. Grand Rapids: MI, 2004, 173-181.
} 
In addition, Parshall's analysis in contextualizing forms in both the missionary and the new believers has given an idea of contextualization in the Bugis context that needs to be considered critically. The missionary's lifestyle has to be appropriate with the local lifestyle, such as: dressing and community daily life. Four points to notice: ${ }^{42}$

- Missionary men wearing the clothing of the target group, that is, the clothing of the village farmer and the wives wear the dress of village women.

- Several of the missionary men have full beards; this corresponds to the appearance of a Bugis religious men.

- Lifestyles are simple.

- Time is regarded, not in absolute terms as in the West, but as event-oriented.

The new believers still practice forms that are adopted from the previous religious culture:

- A place for prayer covered by plaited mat.

- Shoes are removed before entering the worship center.

- All worshippers sit on the floor.

- Bible is placed in front of the leader.

- Eyes are closed, and silence at prayer time.

This form is also applicable in the current context of the Bugis community which is dominated by Islam. It was mentioned in sectionthree that Islam was successfully disseminated and inculcated as the major religion in South Sulawesi and among the Bugis in particular. Islamic resurgence in this area which is indicated by the implementation of the Syariah having been accepted widely among the Muslims demands Christian mission to be more sensitive in its missiological encounter. Christian mission should not only try to find appropriate forms in terms of indigenous Bugis setting but also the form that is applicable in the Islamic context especially the type of Islam which is practiced among the Bugis.

\subsection{Dialogue and Christian Identity}

Where is the place of Christianity in relation to other religions in a pluralistic context? This issue had been highlighted during the Conference of the World Council of Churches in Nairobi, $1975 .{ }^{43}$

\footnotetext{
${ }^{42}$ Parshall, New Paths, 25.

${ }^{43}$ WCC report In Olaf Schumann, "Dialog Antar Umat Beragama: Di manakah Kita Berada Kini?” (Jakarta: LPS-DGI, 1980), 29.
} 
Christianity cannot be apart from the pluralistic world as God has called and sent into this circumstance. Christians, in this reality, will always encounter others who come from different races and cultures, have different perceptions, languages, ideologies, and also from different faiths. In the midst of this diversity Christians, however, need to be sensitive and listen carefully to what other people say by creating dialogue and bringing divine light to them based on love and peace. ${ }^{44}$

The conference in Tambaran, 1938 had formulated a new frame for church growth that indicated the transferring of the responsibility of evangelization from Zending (mission Institution) to local churches, especially in Asia and Africa. ${ }^{45}$ The major point related to this new frame was interest in dialogue to open the way for multifaith encounters in communicating the Gospel. But it can only happen when all parties have the same understanding of dialogue and stand on the same perspective of the reality of life in relation with others, that 'God has created mankind and nations from one man', and for Christians it was created according to the image of God. ${ }^{46}$ In this way, dialogue will lead to a mutual relationship without denying the possibility to influence people or to be influenced by others.

Important to note, dialogue is not merely about the theology or ideology of religion but includes also the reality faced in the society, such as: poverty, injustice, violence and criminal, etc. Christianity should be the motivator in dialogue among other faiths with the intention to find the solution toward these issues. With this in mind, Christians will enter dialogue with a clear purpose that is to fulfill the Great Commission (Matthew 28:19-20; Acts 1:8) ${ }^{47}$ by translating the good news of God's mighty works in Jesus Christ through their actions so that all people experience it in their actual daily lives.

44 "In the same way, let your light shine before men, that they may see your good deeds and praise your Father in heaven." (Matthew 5:16, NIV).

${ }^{45}$ Carl F. Hallencreutz, "Sebuah Pokok Permasalahan Lama: Dialog Dalam Sejarah Oikumene 1910-1971" in Olaf Schumann, "Dialog Antar Umat Beragama: Darimanakah Kita Bertolak? (Jakarta: Litbang-DGI, 1982), 10.

${ }^{46}$ Then God said," Let us make man in our image, in our likeness..." So God created man in his own image, in the image of God he created him; male and female he created them. God blessed them and said to them," Be fruitful and increase in number; fill the earth and subdue it..." (Genesis 1:26-28).

47 "Therefore go and make disciples of all nations, baptizing them in the name of the Father and of the Son and of the Holy Spirit, and teaching them to obey everything I have commanded you. And surely I am with you always, to the very end of the age." (Matthew 28:19-20, NIV). 


\section{Practical Ways to Implement Incarnational Mission in Bugis Context}

\subsection{Building Relationship}

Christian witness among the Bugis people is called to testify to this common task. In some countries, this means that Christian witness begins with Christ-formed identification and solidarity with people who live on the edge of human survival. This identification and solidarity may include public health, combating disease, prostitution, homelessness, and joblessness.

Building relationships is a significant starting point for Christian mission that helps missionaries to acknowledge local people and the context of ministry. The strong communal life pattern practiced among the Bugis will make it easy for missionaries to be in contact with every one in the community. However, missionaries need to contextually consider the life pattern of the local people, so that it does not create cultural distraction or even conflict.

With a majority of Muslims in the Bugis community, building relationships will help to reconcile Christian and Muslim relationship that had broken off in the past and which also can bring forgiveness as well. This can only happen if Christians open their heart to love them. Basically, we know how to reach them - we have all the knowledge - but if we do not have love, we can do nothing. Love believes all things and love receives all people. Without love our mission cannot make sense in the lives of the Bugis. Love is the foundation for the bridge to the Bugis people. Christian love can be expressed by generosity and hospitality, and treating them as part of our family although they embrace a different religion.

\subsection{Developing Spirituality and Character}

Spirituality and Character are two basic elements needed to be developed among the indigenous Bugis Christian. Developing these elements are a significant way to make a strong foundation for the indigenous Bugis Christians so that they are enabled to stand firmly in their faith in their own context without getting trapped in syncretism or getting influenced by the secular world. There are two programmes suggested for this:

\section{- Spiritual Care}

Spiritual care is one of the significant forms of ministry that need to be addressed among the Bugis people who live in this contemporary context, especially those who face depression, stress, and all kinds of problems which are linked to their spiritual lives. This approach is all about caring and nurturing with sensitivity, 
sympathy, and empathy to refresh, restore and strengthen the spirituality of people. It is the responsibility and privilege for each one of us to allow ourselves to become a touching place, giving space and permission to people to find a truth that dignifies and heals. It is up to each of us, by the quality of our touch, our gaze, our presence, to communicate with the heart of God. ${ }^{48}$ In the midst of distressed conditions, addressing spiritual care seems like a challenge for our own spiritual maturity. However, it is those unpleasant experiences which many times enable us to help others grow in spirituality.

On the other hand, spiritual care in the Bugis context is also intended to be a method for helping the Bugis Christians grow in maturity in their faith. It is noted that many among the Bugis Christian are not really rooted in their faith. They are living in what is called a dualism world, religious and secular, that so often does not interlace with each other in their daily life. In addition, many of the Bugis embraced Christianity following their leader or the head of household or it was just like an inheritance from generation to generation without proper understanding of the Christian faith. These nominal Christians need spiritual care to help them stand firmly in their faith especially when they live in an Islamic society as a minority group.

\section{- Indigenous Leadership Training}

To effectively carry out the ministry, Christian mission should provide training for the local people to reach their own community. This foundation helps them communicate the Word of God to their people using their own language, traditions, and culture in a contextually sensitive manner.

It has been noted in the history of Christian mission among the Bugis of a focus on leadership form used by the Dutch missionaries in training and equipping indigenous Bugis Christians to be leaders or ministers who successfully communicated the gospel contextually and brought people to embrace Christianity.

This form can be applied in the current context by training Bugis Christians to be potential leaders in the group or community. It is suggested to use the concept of 'the Bugis for the Bugis leadership pattern' which seems more effective in the Bugis context because those who are trained had known the context closely.

\footnotetext{
${ }^{48}$ Penelope Wilcock, Spiritual Care of Dying and Bereaved People (Pennsylvania: Morehouse Publishing, 1996), 2.
} 


\subsection{Social Concerns}

One of the applications of missionary work is social concern, which developed in this form among evangelistic movements since the World Evangelistic Congress in Lausanne, 1974. Previously, in 1966 although the conception of 'social concern and evangelization' had been introduced, although in a small scale, a significant minority of the delegates maintained that if evangelism was to be effective it must be accompanied by social action. ${ }^{49}$ The Congress in Lausanne affirmed a theological conviction, that:

God is creator and judge of over all the creatures; therefore we must take part in his apprehension for the sake of justice and peace within the human race, and for freedom of men and women from all kind of tyrants... We insist that evangelism and socialpolitical involvement, both are Christian obligation. ${ }^{50}$

This theological conviction has been re-affirmed in the Congress of Lausanne II in Manila, July 1989 with specific focus on social justice and peace. The Final declaration is known as the Manila Manifesto; it states that the biblical gospel has inescapable social implications'. It emphasizes that the love of God is real and is revealed in social justice, human dignity, food, and place to stay. The Kingdom of God demands us to denounce all kinds of sin, injustice, and tyranny. Thus, evangelization should have correlation between Word and action, indeed both have to integrate. ${ }^{51}$

In this sense, the social dimension of the gospel needs to reveal and balance with the spiritual dimension in which up till now was the starting point of evangelization The Gospel as the good news of redemption and reconciliation does not touch only certain areas of humanity, but its substance has a 'holistic' dimension that integrates and incarnates. We need to clarify that Christian mission does not just carry out social concerns as one of the programs or strategies to win people for the Kingdom of God, but it is an obligation to all believers. The Kingdom of God as the goal of history will be

\footnotetext{
${ }^{49}$ Timothy Chester, Awakening to a World of Need (England: Intervarsity Press, 1993), 13. This congress held at the end of October 1966 in Berlin, where nearly a thousand evangelicals gathered from across the world.

${ }^{50}$ Richard A. D. Siwu, Misi dalam Pandangan Ecumenical dan Evangelikal Asia (Jakarta: BPK-GM, 1996), 336-337. (Translated by the author from the original book, Indonesian text)

${ }^{51}$ Richard A. D. Siwu, Misi dalam Pandangan, 337.
} 
presented through social concern, while the good news of redemption will transform to the individual, community, and nation as well.

\subsection{Church Planting}

The main aim of implementing incarnation mission in the Bugis context is the planting of new Churches among the new Bugis believers. This is applicable in the areas where no other churches have been planted or they are out of the reach of any Church. As we look at the ministry map of the Christian Church in South Sulawesi, it only covers certain places in Bugis areas like Maros, Pangkajene, Soppeng, Bone, and Luwu (see the map). Nevertheless, in those areas its ministry is generally concentrated on the Christians who are living in the area around the church. However, the Church, especially regular visitations from the pastor, also minister to those who are living in the rural areas that are far from the Church.

Van Rheenen defined Church planting as initiating reproductive fellowships that reflect the Kingdom of God in the world. $^{52}$ As the reflection of the Kingdom of God in the world, the new church that is planted among the new believers should not separate from other churches, as the unity of the body must be preserved. Hence, the purpose of church planting is not merely to build a new church to increase the number of the churches; however it also goes to show that this is an institution for the function of fellowship. Based on this understanding, a missionary who does church planting among the new Bugis believers has to include two aspects, 'cultural-fellowship' and 'ecclesia-incorporation.'

Cultural-fellowship means the church should be a contextual church within the local culture. Herewith, the church planters must visualize what God's church should look like within their target culture and seek to implement this vision. Thus, in Bugis culture the church must reflect the presence of God because it is the distinctive people of God called by him through his mission and set aside for his mission. However, the form of the church should relate to the cultural form. These forms include such items as language, worship, liturgy, and decision-making.

By using this form Christian thoughts must be communicated in indigenous form, so the people of the land should not perceive the church as foreign religion but as a part of indigenous society. This does not mean that Christianity simply compromise or that

\footnotetext{
${ }^{52}$ Gaylin van Rheenen, Biblical Foundations and Contemporary Strategies of Missions. (Grand Rapids, MI: Zondervan Publishing House, 1996), 148.
} 
syncretism with local belief elements will take place. It means that Christian belief will be communicated in terms acceptable and meaningful to the culture in which the church is planted. Herewith, the church also must plant in terms of relationship ties with the people and their culture together. ${ }^{53}$ As in the implementation in the Bugis context, we should learn from the history of Christianity among them of how the early missionary movement did not use the right way in terms of cultural-contextualization. The superiority that was shown towards the local people and their culture became the main inhibiting factor for mission in that period.

In terms of ecclesia-incorporation, McGavran concurs: "Would be the disciples must be joyfully built into his body - they must not wander alone in the wilderness". Van Rheenen comments that: Too frequently a few new Christians are left to fend for themselves after a short campaign. New converts are led to the Lord and then left before a fellowship of believers has come into existence. These few Christians will likely fall away from God because they have not been incorporated into a fellowship that can form and guide them in their spiritual journey. ${ }^{54}$ It can be noticed two aspects here that is the new believers should be incorporated into a fellowship with other believers and also with other churches. So, they are then able to work together and encourage each other in their spiritual journey.

\section{Concluding Remarks}

Christian missions whether organized by the church or on a personal basis must be understood as Missio Dei (God's mission). All the way through the Scriptures, God takes the initiative, sending his son so the world might be saved through him. When God comes to a person, He always reveals himself and his activity. That revelation is always an invitation for the individual to adjust his life to God. None of the people who encountered God could ever remain the same after it. They had to make major adjustments in their lives in order to walk obediently with God.

As we exist in this Bugis context, we have to discover the elements that could be used as an effective bridge to communicate the Gospel to the people in this situation. This process can be manifested into some forms, but we still have to critically examine them according to God's plan which is centered in the conviction about Jesus Christ, the living

\footnotetext{
${ }^{53}$ Van Rheenen gave general guidelines for effective planting of new churches. Some of these guidelines are applicable in Bugis context (Gaylin Van Rheenen, Biblical Foundations), 150-152.

${ }^{54}$ Gaylin Van Rheenen, Biblical Foundations, 148.
} 
Lord, which we know to be central to God's purpose for humanity. Christian mission is an incarnational mission, which must truly speak to the reality of the Bugis context. The God we proclaim in Jesus Christ is the Creator and Sustainer of the whole universe and all things in it.

\section{CONCLUSION}

\section{Summary}

Culture as a medium to develop the cultural and ethnic identity of the Bugis was mostly denied at the early encounter of Christianity with the indigenous people in South Sulawesi. The people who were baptized had been given a new identity to identify their Christianity. But on the other hand, it brought them out from their own cultural identity that had shaped them. In several areas, Western elements influenced them very strongly, like the dress code, name, and some customary practices in society. In this case, it is not surprising if Christianity, which is often identified with western culture was not really accepted by the Bugis majority, because to them culture is an integral part of their lives as well as their ethnic identity.

In fact, it cannot be denied that the personal identity of the Bugis Christians was not fully manifested by adat alone. Christianity had given them new forms and norms that can be used as elements to establish their identity. However, the new forms and norms, which are based on the Bible, do not have to replace all the elements of local culture, because there are certain elements that are common with the gospel. These elements are good points of contact for missiological engagement, through which gospel and culture have an integral value to transform society. In this case, the Bugis Christians are not living in a dichotomous world, where there is confrontation between gospel and culture, but in a dialectical world.

The history of Christian mission covers a long period and cannot be separated from the situation that prevailed in it, which can be analyzed through observing the practices, habits, and concerns of a representative sample of Christians. The diversity and coherence that appeared in every century from the first to the twenty-first of the history of Christianity should not be an obstacle in interaction between Christianity and the context. But it will be a media for observing and evaluating the totality of Christian mission in communicating the Gospel. During this process one can see how the gospel [Christ] is translated into the local forms and has been absorbed by the believers as well as transforming and discipline the believers themselves. 
Presently, Bugis Christians are trying to reclaim the role of custom to develop personal and ethnic identity, even though some of the elements have changed in meaning or have been rejected. The principles of morality like Rebba sipatokkong, mali siparappe, sirui menre' tessirui no', malilu sipakainge'-mainge'pi mupaja [support each other, encourage each other, love each other, and remind each other], are still holding firmly and used as the philosophy of Bugis life.

Another principle, which is still being practiced, is:

TauE ri Dewata [the fear of God],

Siri'E riwatakkaleta [respect oneself],

Siri'E ripadatta rupa tau [respect our neighbor].

Christianity can slowly engage with the Bugis culture and transform its values into those principles. Like many other Christians, the identity of the Bugis Christians as witnesses of Christ is about sharing the Good News about God's acts in Jesus Christ, to which all people are called to experience it in their lives using the forms and meanings from their own context (Cf. Matthew 28:19-20; Acts 1:8; 1 Peter 2:9-10).

The Bugis Christians, in relation with these cultural-religious forms, will be able to bear witness to Christ and present him in the midst of religions and cultures. Thus, Christ can be revealed in every religion and culture as the only Savior - using the form and the meaning - but he is not the monopoly of Christians. This emphasizes the uniqueness and universality of Jesus Christ that God sent his only son to redeem and save human beings who believe in him from all religions and cultures (cf. John 3:16).

As Christians we can witness and work as though God is at work behind the scenes of the plurality of world religions [and cultures], pushing them forward into a final unity that is incorporated in Jesus Christ. There are no two ways for salvation. There is one salvation, one way to salvation, one savior of the world, and that is the eschatological salvation valid for all through the one who came that all might find life, who died that the world might be reconciled, who was raised that hope might live for the victory of God and the restitution of all things in him. ${ }^{55}$

${ }^{55}$ Carl E.Braaten, "The Uniqueness and Universality of Jesus Christ" in Gerald H. Anderson and Thomas F.Stransky, (ed). Mission Trends No.5: Faith Meets Faith (Grand Rapids, MI: Eerdmans, 1981), 85. 


\section{BIBLIOGRAPHY}

Books

Anderson, Gerald H. and Thomas F.Stransky, (ed). Mission Trends No.5: Faith Meets Faith. Grand Rapids, MI: Eerdmans, 1981.

Abdullah, Hamid. Manusia Bugis Makassar. Jakarta: Inti Idayu Press, 1985.

Chester, Timothy. Awakening to a World of need. England: Inter-Varsity Press, 1993.

de jong, Chris G.F. Ilalang Arenna . Jakarta: BPK-GM, 1996.

Kane, J.H. Christian Missions in Biblical Perspective. Grand Rapids, MI: Baker Book House, 1976

Lingenfelter, Sherwood. Transforming Culture. Grand Rapids, MI: Baker Books, 2004.

Moen, Andi. Menggali Nilai-nilai Budaya Bugis-Macassar dan Sirik na Pacce. Macassar: Mapress, 1990.

MPS-GKSS, Angin Menderu, Ombak Mengguncang: Sejarah Singkat Gereja Kristen di Sulawesi Selatan. Makassar: MPS, 1996.

Neill, S., Gerald Anderson \& John Goodwin, Concise Dictionary of the Christian World Mission. London: Lutterworth Press, 1970.

Niebuhr, Richard H. Christ and Culture. NY: Harper Torchbooks, 1975.

Parshall, Phil. Inside the Community: Understanding Muslims through Their Traditions. Grand Rapids MI: Baker Books, 1994.

Pelras, Christian. The Bugis. Cambridge: Blackwell Publishers Inc, 1996.

Schumann, Olaf. Dialogue Antar Umat Beragama. Jakarta: Litbang DGI, 1982.

Siwu, Richard A. D. Misi dalam Pandangan Ecumenical dan Evangelikal Asia. Jakarta: BPK-GM, 1996.

Taylor, W.D. Global Missiology for the $21^{\text {st }}$ Century. Grand Rapids, MI: Baker Academic, 2000.

Teixeira, Fr. Manuel. The Portuguese Missions in Malacca and Singapore (15111958) Vol.II-Malacca. Lisboa: Agencia Geral Do Ultramar, 1961.

van Rheenen, Gaylin. Biblical Foundations And Contemporary Strategies Missions .Grand Rapids, MI: Zondervan Publishing House, 1996.

Volkman, Toby Alice and Ian Caldwell. Sulawesi the Celebes. Singapore: Barkeley, 1990.

Wilcock, Penelope. Spiritual Care of Dying and Bereaved People. Pennsylvania: Morehouse Publishing, 1996. 


\section{Project Reports}

Toms, Douglas F. Foundation Pour L'aid Potestantisme Reforme. Foundation Aiding Bugis Poor Parishes: Ujungpandang, March 1999.

Bulletins/Magazines/Journals/Electronic

Andaya, Leonard Y. Bugis Diaspora, Identity, and Islam in the Malay World. Macassar: International Workshop, Macassar Golden Hotel, 5-8 June 2003.

Encyclopaedia Britannica Library. "Sulawesi Selatan" [CD-ROM]. Chicago: Encyclopaedia Britanica, Inc, 2003.

Said, Nurman. Religion and Cultural Identity Aong the Bugis. Inter-Religio Bulletin, no.45, Summer 2004.

Samuel, V. "Mission as Transformation" in Evangelical Perspective on Mission and Ethics. Dristikone magazine: April-July 2002. 